\title{
To What Extent has the EU Taken away the Sovereignty of its Member Nations?
}

\author{
Udhava Gupta
}

\begin{abstract}
This research focused on the perceived impact of the supranational institutions of the European Union (EU) over the sovereignty of its member nations. This paper also attempted to show how the EU evolved from an economic union to a monetary union that currently supervises almost all decisions made by its member states. This research analyzed various treaties, organizations and international agreements of the EU that affect the sovereignty of member states in various ways with the aid of secondary research.Secondary data from academic journals, research papers and articles was useful in understanding the real politics behind the European Union's working. This research highlights the extent to which the EU has withdrawn the authority of its member states to make decisions for its citizens. This research found that Britain's exit from the $\mathrm{EU}$, to some extent, was fueled by the loss of sovereignty Britain felt after becoming a part of the European Union. In conclusion, the research showed that the EU had taken away the sovereignty of its member states to a great extent but it was not done intentionally - it was done in order to be able to offer the promised benefits to all its member states.
\end{abstract}

Index Terms - European Union, Lisbon treaty, Schengen area, Brexit, Monetary union, supranational institutions.

\section{INTRODUCTION}

The European Union is one of the most eminent political, social and economic unions that signifies and sustains European unity - the state of all 28 member nations being united as a whole. There persist contrasting opinions about the European Union's working and organization. Euroscepticism is the criticism of the European Union and European integration that has rose out of the diverse opinions about EU and its role in maintaining peace across Europe. The head of UK independence party- Nigel Farage, claimed the European union as a "Bureaucratic monster" because of its policies and laws. The main argument revolving around the rise of Euroscepticism across Europe is the compromise of national sovereignty to proliferate EU's powers.

European union was originally known as European Economic Community (EEC) and was established in 1957. Its aim was to promote free trade and commercial cooperation among the nations of Western Europe. It started with 6 member nations and eventually developed into the European Union in 1993 after the implication of Maastricht treaty. What started as an economic organization now has control over all diplomatic, societal and financial policies of all member nations. The arbitrary implementation of various policies by EU in the member nations shows us that it, to a certain extent, does

Udhava Gupta, $12^{\text {th }}$ Student, Neerja Modi School, Jaipur threaten the sovereignty of the member nations. In this paper, we will see how the EU works and what is its structure andto what extent does it threaten national sovereignty of its member nations.

On 23rd June 2016, a referendum was held in the United Kingdom because of the rising Euroscepticism in the whole of Britain. The referendum was held to decide whether or not UK should remain an integral part of the European Union. The results were as follows - 52\% voted to leave and $48 \%$ voted to remain - which caused a chaos all around the globe, since UK reached a conclusion of exiting the EU which led to alteration of global peace. The reason why people are willing to leave the EU despite knowing the costsis because they strongly believe that $\mathrm{EU}$ is doing more than good to its member states and they would be better off not being a part of it. The central argument, though, is that EU policies force nations to compromise their national sovereignty which goes against the interest of both the people and the government. This is the reason the people of UK concluded that despite the possible deterrent costs of exiting EU, they shall leave it to be able to prosper in the future.

This issue of Euroscepticism emerged in recent years because the European union has transformed from an economic union to one that takes decision over every minute issue, from immigration control to judicial independence, completely taking away the power from the hands of the national governments and giving it to the EU officials and its supranational institutions. This shows that how it's the compromising of the member nations sovereignty by the European Union, that hurts the feelings and sentiments of people propagating them to become Eurosceptic and stand against the $\mathrm{EU}$ and its legislation.

Te formation of a multinational European framework has forced nations to compromise over various fields including their national sovereignty. But it's not exactly the eradication of member states' sovereignty, as now there are 28 states that have come together and collaborated rather than giving away their rights to some third party and they now exercise power keeping in mind mutually assured welfare of all the states.

The European Union has divided itself into several bodies that are accountable for the working of the EU; each branch is responsible for different set of work. The European parliament consists of national representatives of the member states who deliberate over EU laws, budget and trade agreements and come up with policies that legislate across all states. Even though the policies, to some extent, do reflect national interests of member states, the association has led to several limitations on the governing systems of the member 
states.

Despite several provisions the EU provides to the national governments of the member states, it still threatens and undermines national sovereignty of all member states. Also, its policies are getting cruel and tyrant day by day, which is evident by their new law of a fee being charged on nations that don't comply to EU courts. This has arisen questions on whether EU's development over the years is going in the right way or not. (https://www.bbc.com/news/uk-politics-eu-referendum-3563 0757).

National sovereignty is defined as the authority of a state to govern itself with no power beyond the state. This definition shows us that how the European union directly challenges the national sovereignty of member states at every point, as it tends to be a power beyond the state which is a principle against the very definition of sovereignty. This shows us that how the evolution of EU and its expanding powers has led to the deterrence of sovereignty and an increment in rampant ideologies such as Euroscepticism in the whole of Europe leading to people, even government officials, terming the EU as "gravedigger of state sovereignty".

\section{What really lead to the question of sovereignty arising in the European Union?}

\section{THE TREATY OF LISBON}

When we talk about the legal aspect of the European Union, it has recently been reformed and come to power. The union operates under the treaty of Lisbon that was drafted in 2007 (October) and came to force in 2009 after getting approved from all member nations. The Lisbon treaty came in as a reform but behind the reform was a reason, which made its entrance in the EU unavoidable. It came in as a result of a huge controversy that was caused by the European constitution.

Luckily, the European constitution was rejected by two author states of the European Union, or else the EU today would've been even more domineering as a clause of the former European constitution enabled EU law to be supreme over national laws. These rejections and proposals of amendments by new member states made the European constitution a bit more neutral and gave more power to states, or else today we might've not been discussing this issue because if the European constitution wouldn't have been rejected, the EU would've already surpassed and taken over the sovereignty of its member nations.

A number of provisions of the constitution treaty were retained as a part of the Lisbon treaty, as they were considered to be essential for a mutually assured collaboration between the member states. A major reform that took place in the transition was the abolishment of three-pillar structure of EU that was introduced earlier during the Maastricht treaty. This reform had several repercussions in the organization and working of the EU such as the European parliament gaining an upper hand while deciding budgetary, agriculture, and immigration laws.

Because of the failure of the European constitution,initially the EU was only able to directly influence the economic policies, all the other affairs such as policies concerning education, health, tourism were left under governance of the national government itself. But with time, grew the power of $\mathrm{EU}$, and it started to infringe policies other than economic ones too, slowly and slowly absorbing the power earlier left to the state authorities.

It is claimed that the Lisbon treaty was formulated to preserve the sovereignty of the member states of EU, by amending the two treaties, which form the basis of the union. But in the real world, the situation is in contrast to the claim. Even though the Lisbon treaty provides privileges such as - member states can oppose EU legislation when national interests are hurt, even the European commission power was reduced. But in real world, these laws are not taken seriously and they end up breaking and infringing the national sovereignty of its member states.

\section{EUROPEAN INSTITUTIONS}

After the Lisbon treaty was implemented in the European Union its power divided into a number of institutions that became the ruling powerof the whole union: the European Commission, the European Council, the Council of Ministers, the EU parliament and the European Court of Justice. The extent of power and field in which the power is exercised is very different for each of the institutions. If weevaluate the amount of influence of each of these institutions on national sovereignty of EU member nations, we must alsoassess the prominent matters concerning each institution in common, which are: (a) whether the national governments are equally represented, so that no one can exercise superiority over others? (b) Do all states have equal say in legislation? And (c) Do the states have the audacity to influence or resist the legislation of these parliaments?

All 28-member nations of the European Union have one representative of theirs at the European commission, who decides upon the legislative drafts and budgets of the union. Nonetheless it also acts as a liaison between the other European institutions and member states. The European commission also holds the responsibility of executing and supervising fluent working and obedience towards EU policies by member nations. Although it holds the executive power of the EU, it's mainly to regulate the member states to implement policies they earlier committed to do and did not strongly enforce.

Next, in the EU institutions, comes the Council of Europe, which upholds the responsibility of determining the social, economic and political primacies of the European Union. It doesn't uphold any hegemony over other institutions, though, itselfis mandated under the Treaty of Lisbon, which compels the European commission and terms it to be responsible to "define political priorities". All major, complex and infringing issues are deliberated and decided upon by the council of Europe which holds meeting four times a year. The commission consists of member nation representatives in 
order to come to decisions that don't hurt any nations' interests and laws.

Though these institutions are responsible to make laws and policies that need to be followed by the member nations, recent cases like the BREXIT has shown that if some policy or laws go against a nation's interest and security, they have all rights to rule against it. The next body of the EU is the European court of justice. The foremost duty of ECJ is to assure that there is equal representation of all member states when there is any law made, passed or ideated upon. The period for which a representative has the right to represent in the ECJ is for a total term of 6 years. The ECJ has the undaunted right to infringe in cases of the state, though there persist several limitations in regard to it. In recent years, this increase in authority of the institutions of Europe and them being placed below the institutions of the EU, has threatened the member states of their authority in EU and hence pondered upon the threat EU poses to national sovereignty, which all the institutions' we discussed, to some extent, do hover.

The Council of Ministers also consists of the representatives of the member states-ministers, the same way as other institutions do. But they're a bit differentdue to inequality of votes assigned to member states. The countries with higher population have their vote's value incremented in comparison to other member states.Also, it acts as a legislative body in the EU.

Higher population states turn out to have abaseless advantage when it comes to getting bills and passing laws in the EU. This is because every country gets a vote, which upholds value in accordance to the population of that state, and so states such as France have an upper hand in getting a law passed than a smaller one for instance Denmark. This advantage turns out to be unfair for the smaller states of EU, as now they no more uphold equal voice while making policies for their own people. Not just this, but also the EU parliament, to some extent, makes the EU biased to some countries, as seats are provided to member states on the basis of the population: higher population, higher seats. For example, Germany generally has a higher authority to get reforms in policies than Malta does.

All of these policies together show to us that to some extent the major power of EU rests in only a few hands and that's what undermines the national sovereignty of a number of nations.

There are various more instances, which suggest that the European union has taken away the sovereignty of its member nations on several different levels. Firstly, the European states national sovereignty had been disintegrated to some extent because of the implication of QMV (qualified majority voting), according to which the EU required only a majority of votes, which implied that member states had to oblige to adopt to policies that they may, in general, oppose.

Secondly, the national sovereignty is further deteriorated because of the International European institutions that, by the EU, have been granted enormous amount of powers in the field of policies, which were earlier in access of only member states. This is even more problematic because these institutions are composed of the European community rather than a national representative, which meansthe member states views are completely ignored in the whole framework. An example is the undaunted power of the European commission, which leads to it being viewed as a major limitation to national sovereignty because it has a role of policy leadership and hence it exercises substantial influence over their outcomes, mostly in regard to the EU market. Also, the increment in the regulatory power of EU in the single market has expanded the commission's power while being a deterrent for the nation's sovereignty. Another evidence for the extreme power of EU institutions is evident via the European parliament. Its power has been increased a lot through the legislative procedure, which has given equal power to both the parliament and council of ministers on regulation of the single market and many more issues such as transportation and immigration. Another thing that has got fragmented due to this is popular sovereignty. This is because national governments are accountable to parliament and voters, not the EU institutions who indirectly are insulated from direct control by voters. This all has thus caused an alarmingly high level of democratic deficit completely breaking the link between the citizens and the decision-making authority. The increased role of the European parliament has thus not been able to provide the EU that amount of legitimacy as national democratic institutions did.

Thirdly, the sovereignty in parliament and the legislature has been eradicated by the primacy of EU laws. An example of the same is the Community law that implies that in cases of conflicts between EU and national law, it's the EU that'll be considered completely demeaning the national laws. All these things have led to shaping people's belief of the EU taking away the sovereignty of its member nations bit by bit.

\section{SCHENGEN AREA}

The European union guarantees several superficial rights to its people, one of them is the right of free movement that can be exercised by anyone, and this gives all citizens of EU states' the right to work, live and travel in any EU country, without any hefty procedural works. What's even more scrutinizing in this perplex scenario is what's guaranteed to the people by the Schengen co-operation. It allows people to change countries, cross borders, without any kind of security check, which is a major argument against the security and sovereignty of every member nation. What's even more cruel is that even tourists and businessman have the right to access this policy, despite not being EU citizens, and this had led to several terrorist attacks such as the one that took place in Eiffel tower, in 2016- due to lack of security check that's being imposed by the EU itself.

We talked about the fact that EU considers itself not taking away sovereignty of member states rather collaborating nations, but this Schengen area policy, seems more than 
collaboration because, in nature, it is oppressive for all the EU countries. And this is not just a statement made by the countries, rather it's evident that this policy is a burden on state security and sovereignty after the several terrorist attacks that have taken place in various EU countries Because the countries weren't allowed to check the people who cross their borders, it led to terrorist organizations' such as Taliban and Al-Qaida to enter all EU countries.

The several terrorist attacks have shown that this Schengen area policy does more harm than good to the European Union, and surely does infringe on individual state sovereignty. By taking complete access of border control and security of member states, the EU institutions' have turned out to be deterrent rather than advantageous for the people. As by enabling this they've made it a worse case scenario for all of them.

\section{BREXIT}

As discussed earlier, the most evident argument in favor of Brexit is that of the lost sovereignty of Britain to the hands of the EU, and its worldwide institutions. Conservative politicians of Britain, such as Boris Johnson and Michael Grove, also express similar argument.In the past few years, the EU treaties have taken a toll over national policies by shifting the power from the member state authorities to EU authorities in Brussels. In today's time, almost all major decisions for all member states are taken by the EU rules and not the national rules.

A lot of people have raised voice on the issue that the EU's executive branch, called the European Commission, isn't directly accountable to voters in Britain or anyone else. Another burden is that those ministers are not accountable to anyone, making national government responsible to answer the people for any flaw, which doesn't make sense because it's not them who're making laws. All these things have also given rise to eurosceptisicm throughout the European Union.

Argument for immigration has been that the Britain would never be able to fully control the influx of immigration on their land until it leaves the EU because EU's freedom of movement policy gives other EU citizens an automatic right to live in Britain or any other EU state. When we talk about controlling the crime rates, the EU arrest warrant forces Britain to send all people charged for crime to the Brussels court which is a financial burden for government and demeans the national judiciary body of every member state leaving EU would get the states off this track.

All of this boil down to the "EU's sovereignty paradox" that the UK believes it may just escape through Brexit. All the major problems UK's facing such as the refugee crisis, euro zone crisis highlights that no amount of rhetorical flourish about multilevel governance or Europe's union can wish away: member states have ceded too much control to the supranational level to be able to set effective policies in important areas independently of each other and of the Union institutions. And hence Britain strongly believes Brexit is the key to gain back their sovereignty and once again emerge as a super power.

\section{CONCLUSION}

The question of sovereignty in EU is far more complex than the current referendum debate implies. Reviewing the prospects for member states inside or outside the EU, reveals the illusory notion of absolute sovereignty in a world that is more interdependent today, than it was when the EEC was formed.

The principal trade-off for the lucrative social and economic benefits to the member states, is the loss of sovereign control over the flow of workers from the rest of the EU into their nations. This has caused great public concern and is a principal driver of support for the campaign to leave the EU in the United Kingdom. There is no escaping from this trade-off, since it is a key requirement of EU membership. And hence it is now a formulated option in front of all the EU member states: they can either ripe the innumerable benefits they gain from being an integral part of the EU or they can leave the EU to maintain complete sovereignty. As we've seen through the paper, it's essential for EU to undermine national sovereignty of member states to be able to be a successful integrated union.

And hence, I'd like to conclude by saying that to a higher extent the EU has taken away the sovereignty of its member states but it has not done it intentionally, it's done it to be able to give the promised benefits to all the member states.

\section{ACKNOWLEDGMENT}

This research was partially supported by Mr. Saurabh Modi, Chairman, Neerja Modi School. I thank my colleagues from various institutions of Jaipur, Spain, Massachusetts, and New York for providing meaningful insights through spirited discussions.

I thank Meesha Gupta for taking out time from her hectic schedule at Union College, New York and helping me gain a better understanding of research and facilitated my growth as a researcher.

I would also like to show my gratitude to Mrs. Sarita Nathawat, My IB History HL teacher and IBDP coordinator, for being my mentor and research guide throughout the arduous process of research and publication.

My acknowledgments would be incomplete without expressing gratitude to my alma mater, Neerja Modi School, Jaipur which has been the pillar of my knowledge over these years.

\section{REFERENCES}

[1] •www.google.com/url?sa=t\&rct=j\&q=\&esrc=s\&source=web\&cd=3\& cad=rja\&uact $=8 \&$ ved=0ahUKEwismK_Ov-LbAhUCat4KHTK4D5o QFgg6MAI\&url=https\%3A\%2F\%2Fcogitariumlancaster.files.wordpr ess.com\%2F2012\%2F06\%2Fdoes-membership-of-the-eu-underminenational-sovereignty.pdf\&usg=AOvVaw2scjuBa8Wbh_rFuE7UdtJX.

[2] "Britain, the EU and the Sovereignty Myth." Chatham House, www.chathamhouse.org/publication/britain-eu-and-sovereignty-myth. 
[3] Sovereignty in Theories of European Integration and the Perspective of the Polish Constitutional Tribunal." Www.ce.uw.edu, www.google.com/url? sa $=t \& r c t=j \& q=\&$ esrc $=s \&$ source $=$ web $\& c d=1 \& c$ $\mathrm{ad}=$ rja\&uact $=8 \&$ ved $=0$ ahUKEwiP9sKMke_bAhULpI8KHdwQBOY QFggmMAA\&url=http\%3A\%2F\%2Fwww.ce.uw.edu.pl\%2Fpliki\%2 Fpw\%2F17-2014_czaputowicz.pdf\&usg=AOvVaw07_SVlEmYTO4 BGPBjDBKmT.

[4] Lee, Timothy B. "Brexit: the 7 Most Important Arguments for Britain to Leave the EU." Vox, Vox, 22 June 2016, www.vox.com/2016/6/22/11992106/brexit-arguments.

[5] "“Europe and Sovereignty: Realities, Limits and Projects." Europarl.europa.eu,

www.europarl.europa.eu/the-secretary-general/en/“europe-and-sovere ignty-realities-limits-and-projects."

[6] "European Issues and Interviews." Dublin and Schengen - Restoring Confidence and StrengtheningSolidaritybetweenMember States of the European Union, www.robert-schuman.eu/en/european-issues/0410-europe-and-soverei gnty-reality-limits-and-outlook.

[7] "A CriticalAnalysis of EU Member State Sovereigntyunder the Treaty of Lisbon. Sovereignty v Democracy. - The Student Journal of Law." Google Sites, sites.google.com/site/349924e64e68f035/issue-4/a-critical-analysis-of -eu-member-state-sovereignty-under-the-treaty-of-lisbon-sovereignty$\mathrm{v}$-democracy.

[8] “THE EU AND MEMBER STATES SOVEREIGNTY." RICHEST AND POOREST EU COUNTRIES | Association of Accredited Public Policy Advocates to the European Union, www.aalep.eu/eu-and-member-states-sovereignty.

[9] ProtesilaosStavrou. "Is the European Union Sovereign?" ProtesilaosStavrou, ProtesilaosStavrou, 20 Nov. 2016 , protesilaos.com/eu-sovereignty/.

[10] "Schengen Area - Migration and Home Affairs - European Commission." Social Protection Statistics - UnemploymentBenefits StatisticsExplained, $\quad 6 \quad$ Dec. ec.europa.eu/home-affairs/what-we-do/policies/borders-and-visas/sch engen_en.

[11] Stratfor. "Europe Rethinks the Schengen Agreement." Stratfor, Stratfor, 2 Sept. 2015 , worldview.stratfor.com/article/europe-rethinks-schengen-agreement.

[12] "Be a Global Citizen." Financial Times, Financial Times, www.ft.com/content/d4a3a5c8-3be9-11e8-b7e0-52972418fec4).

[13] Flanagan, Brian. "The Strange Case of Brexit and British Sovereignty." RTE.ie, $\quad$ RTÉ, 2018 , www.rte.ie/eile/brainstorm/2018/0301/944407-the-strange-case-of-bre xit-and-british-sovereignty/. 